ПОЛИТИКА В НЕПОЛИТИЧЕСКОМ: ИДЕОЛОГИЯ КОНСТИТУЦИОННЫХ РЕФОРМ В ПРОГРАММАТИКЕ ПРОФЕССИОНАЛЬНЫХ СЪЕЗДОВ НАЧАЛА ХХ ВЕКА*

Анастасия Туманова
Александр Сафонов

Национальный исследовательский университет

«Высшая школа экономики»,

Москва, Россия

\title{
POLITICS IN THE NON-POLITICAL: THE IDEOLOGY OF CONSTITUTIONAL REFORMS IN PROFESSIONAL CONGRESSES IN THE EARLY $20^{\text {th }}$ CENTURY ${ }^{\star *}$
}

\author{
Anastasia Tumanova \\ Alexander Safonov \\ HSE University, \\ Moscow, Russia
}

This article considers congresses organised by representatives of various professions (technicians, doctors, teachers) on the eve of the First Russian Revolution. Based on documents from the four most important and populous public meetings, the authors conclude that they turned into a meeting place for non-zemstvo intellectuals with public figures from the zemstvo movement, which led to the emergence of a political class. The purpose of this article is to describe the evolution that the congresses underwent based on the analysis of congress documents (meeting records, reports, resolutions, etc.), periodicals, and

* Исследование осуществлено в рамках Программы фундаментальных исследований НИУ ВШЭ в 2021 г.

** Citation: Tumanova, A., Safonov, A. (2021). Politics in the Non-Political: The Ideology of Constitutional Reforms in Professional Congresses in the Early $20^{\text {th }}$ Century. In Quaestio Rossica. Vol. 9, № 1. P. 325-340. DOI 10.15826/qr.2021.1.582.

Цитирование: Tumanova A., Safonov A. Politics in the Non-Political: The Ideology of Constitutional Reforms in Professional Congresses in the Early $20^{\text {th }}$ Century // Quaestio Rossica. Vol. 9. 2021. № 1. P. 325-340. DOI 10.15826/qr.2021.1.582 / Туманова А., Сабонов А. Политика в неполитическом: идеология конституционных реформ в программатике профессиональных съездов начала XX в // Quaestio Rossica. T. 9. 2021. № 1. C. 325-340. DOI 10.15826/qr.2021.1.582.

(C) Туманова A., Сафонов A., 2021 Quaestio Rossica • Vol. 9 • 2021 • № 1, p. 325-340 
political investigations covering their work. It is demonstrated that congresses ceased to be reviews of achievements of certain branches of the national economy (science and technology, medicine, and public education), which were meant to confirm the recognition of their significance by the state. Instead, they turned into demonstrations of the independent position of professional figures on issues of professional and socio-political agenda, into channels for mobilising public opinion in the direction of constitutional reform of the autocratic system and ideological preparation for the First Russian Revolution. The congresses promoted the involvement of the community outside the zemstvo in transforming the bureaucratic system into a legal state and class-based Russian society into civil society. On the eve of 1905, public congresses were an important milestone in the development of the liberation movement in Russia and symbolised its transition to so-called "new liberalism". It was characterised by overcoming the monopoly position of zemstvo activists in the liberal movement and involving various professional groups in Russian society, mobilising public opinion to discuss public participation in political decision-making. According to the authors, professional forums were historically significant as they had an impact on the ruling elite: they let it know about public ideas concerning urgent sociopolitical transformations and ensured public participation in the development of strategies for their implementation. Professional congresses lie at the intersection of several areas of modern historical knowledge: political and social history, the history of ideas, and the history of professions. However, they have not been studied comprehensively so far, and the authors fill this historiographical gap.

Keywords: political history, social history, history of professions, history of ideas

Сюжетом настоящей статьи стали съезды, организовывавшиеся представителями различных профессий (техниками, врачами, учителями) в преддверии Первой русской революции. На основании изучения документов четырех наиболее статусных и многолюдных публичных собраний авторы приходят к выводу, что они стали местом встречи неземской интеллигенции с деятелями земского движения, приведшей к рождению политического класса. Цель статьи состоит в том, чтобы на основании анализа документов общественных съездов (дневников, отчетов, резолюций и пр.), материалов периодической печати и политического сыска, освещавших их работу, показать эволюцию, которую они претерпевали. Показано, что из смотров достижений отдельных отраслей народного хозяйства (науки и техники, медицины и народного образования), подтверждавших признание государством их значения, съезды превращались в акты демонстрации самостоятельной позиции профессиональных деятелей по значимым вопросам профессиональной и общественно-политической повестки дня, в каналы мобилизации общественного мнения в направлении конституционного реформирования самодержавного строя и идейной подготовки Первой русской революции. Съезды содействовали вовлечению неземской общественности в работу по преобразованию бюрократического строя в правовое государство, а сословного российского общества - в гражданское. Общественные съезды кануна 1905 г. явились важной вехой в раз- 
витии в России освободительного движения и символизировали его переход на стадию так называемого «нового либерализма». Для него были характерны преодоление монопольного положения земцев в либеральном движении и вовлечение в него различных профессиональных групп российской общественности, привлечение общественного мнения к вопросам участия общества в принятии политических решений. Историческое значение профессиональных форумов, по мнению авторов, состояло также в том, что они оказали воздействие на правящую элиту: донесли до нее общественные представления о насущных социально-политических преобразованиях и обеспечили участие общества в выработке стратегии их проведения. Проблематика профессиональных съездов начала ХХ в. находится на стыке целого ряда направлений современного исторического знания: политической и социальной истории, истории идей, истории профессий. Между тем она не стала до сих пор предметом комплексного изучения специалистов, ввиду чего авторами восполняется историографическая лакуна.

Ключевые слова: политическая история, социальная история, история профессий, история идей

\section{Время съездов: постановка проблемы и историография}

Последние десятилетия существования российской монархии были временем общественных съездов. Общеимперские и региональные, они проходили в условиях широкой публичности и касались различных отраслей народного хозяйства: науки и техники, медицины и образования и пр. Их организаторами выступали представители профессий: врачи, учителя, технические специалисты. Однако сугубо деловой повесткой делегаты профессиональных форумов не ограничивались. Они выходили на злободневные проблемы российской общественной и политической жизни, а выработанные ими идейные позиции становились формой социального протеста против правящего режима. «Соберите какой угодно съезд, ну хотя бы ветеринарный или фармацевтический, - писал осенью 1904 г. заграничный журнал “Освобождение”, - и вы увидите, что по поводу скотских падежей или аптекарской таксы ветеринары и фармацевты начнут говорить о необходимости политических реформ» [Исторический урок, с. 116].

Политическая платформа профессиональных съездов формировалась под влиянием идеологии российского либерализма, которая, в свою очередь, отражалась на страницах подцензурной газеты «Ocвобождение», в резолюциях земских съездов, а также в программных требованиях кружка «Беседа» (1899-1905) и «Союза освобождения» (1903-1905). За последними объединениями в литературе закрепилось наименование протопартий. Эти организации были предшественниками либеральных партий кадетов и октябристов, они спо- 
собствовали не только установлению устойчивых личных связей их участников, но и созданию алгоритмов поведения и стратегий реформ, определявших политическую повестку в 1905 г. [Соловьев, с. 53-59; Канищев, с. 15].

Профессиональные съезды, о которых пойдет речь в настоящей статье, стали местом знакомства специалистов-профессионалов с земскими служащими. Единение земцев и профессионалов расширяло социальную базу классического российского либерализма, вооружало тех и других опытом обсуждения злободневных общественных вопросов, способствовало нарождению в России политического класса.

Съезды начала прошлого века символизировали развитие в канун 1905 г. публичной сферы и общественного мнения, а также радикализацию освободительного движения. Профессиональные деятели заявили на них политические требования и сформулировали актуальную повестку конституционных преобразований, осуществлявшуюся в годы Первой русской революции. Помимо определения стратегии реформ, здесь вырабатывалась тактика давления на правительство. Подобный подход был характерен для земского либерализма начала 1900-х гг., деятели которого трактовали реформы как результат соглашения между властью и обществом и стремились побудить власть к их проведению через мобилизацию общественного мнения [Соловьев, с. 53-59].

Профессиональные съезды начала XX в. закономерно находились в тени своих более политизированных собратьев - земских съездов и съездов уполномоченных губернских дворянских обществ, ввиду чего их историография весьма скромна. Авторитетный историк российского либерализма К. Ф. Шацилло лишь вскользь упоминает их в своей монографии, посвященной либеральному движению кануна революции 1905-1907 гг. Между тем историк отмечает, что начиная с 1901 г. съезды использовались земскими деятелями для обсуждения актуальных вопросов политической повестки дня, а также способствовали вовлечению в либеральное движение неземской интеллигенции [Шацилло, с. 72-73, 79].

Идеология либеральной общественности рубежа XIX-XX вв. была рассмотрена А. Д. Степанским. Историк связывает развитие русского либерализма в ту пору с кризисом реформаторско-культурнической идеологии, верившей в прогресс на почве самодержавия, со все более очевидным для профессиональных деятелей убеждением в невозможности улучшения отдельных отраслей народного хозяйства без конституционной эволюции монархии. Указывая, что либеральная интеллигенция стояла на более левых позициях, чем земцы, лидерство в либеральном движении Степанский признает за земцами, конституционные требования которых определяли его содержание [Степанский, с. 65-66].

Идейные параметры либерального проекта рубежа XIX-XX вв. рассмотрел В. В. Шелохаев. Он трактовал стремительно набиравший силу либерализм нового типа как заимствовавший у классического 
либерализма социальный капитал (земские кадры) и убежденность в предпочтительности эволюционного пути разрешения политических и социальных конфликтов. В основание выработанного новым либерализмом варианта модернизации страны легли, по словам историка либерализма, идеи конституции и парламентаризма, а также привлечения демократических сил к их воплощению в жизнь [Шелохаев, с. 9-10].

А. Н. Медушевский дополняет характеристику либеральной идеологии начала XX в. отождествлением ее с конституционализмом общественным движением, представленным главным образом интеллигенцией и нацеленным на достижение гражданского общества и правового государства. Вопрос о социальной базе российского конституционализма, то есть силах, способных проводить демократические преобразования, видится этому специалисту наиважнейшим [Медушевский, с. 5-8].

Феномен общественных съездов был затронут в американской русистике. Так, в посвященной различным профессиям (инженеров, врачей, учителей, специалистов в области права) монографии под редакцией Х. Д. Балзера съезды трактуются как средства, с помощью которых специалисты отстаивали свои интересы и боролись за автономию от государства в политическом процессе [Russia’s Missing Middle Class, p. 11]. Дж. Брэдли сфокусировал внимание на научных съездах 1904 г. Пироговском и техническом, признав их наиболее ярким этапом развития публичной сферы и общественного мнения в канун 1905 г. Вслед за дореволюционными российскими публицистами историк именует съезды «парламентами общественного мнения», игравшими существенную роль тогда, когда альтернативных каналов воздействия общества на власть (представительных учреждений и пр.) не существовало [Брэдли, с. 423-424]. В то же время о съездах 1902-1903 гг., изучение которых позволяет проследить эволюцию профессионального освободительного движения, историк речи не ведет.

Обзор основополагающих подходов к проблеме позволяет заключить, что специалисты указывали на значение съездов профессионалов, однако комплексно их не рассматривали. Ретроспективный анализ программ и риторики предреволюционных профессиональных съездов позволяет судить об их мобилизационных возможностях в формировании политического класса и подготовке 1905 г.

Изложение истории профессиональных съездов начала прошлого века будет строиться в контексте трех ключевых исторических этапов, на которых выстраивалась их повестка дня и оформлялись различные типы (модели) публичных собраний. Речь пойдет о четырех съездах, три из которых произошли с разницей в один год. Идеология съезда начала 1902 г. была нацелена на консолидацию общественных сил вокруг конструктивных общественно-полезных идей, тогда как два съезда рубежа 1903-1904 гг. приобрели характер протестных собраний, высказавшихся за конституционный образ правления. 


\section{VIII съезд русских врачей-пироговцев как проба общественных сил}

С 3 по 10 января 1902 г. в Москве проходил VIII съезд русских врачей-пироговцев. Он не походил на торжество под патронатом государства, служившее науке и далекое от политики, которое представляли его предшественники - съезды естествоиспытателей и врачей пореформенного периода, а также пироговские съезды второй половины 1880-1890-х гг. Риторика выступлений его участников и многие резолюции приобрели критическое по отношению к власти содержание.

На торжестве по поводу его открытия делегаты высказали признательность не императору, что было характерно для съездов более раннего периода, а московскому самоуправлению, выделившему помещения и финансы на его проведение. Председатель Московской губернской земской управы Д. Н. Шипов заявил в ответ, что видит миссию съезда в создании «определенного типа земского врачаспециалиста и общественного деятеля», и признал ее значимой ввиду отсутствия в России общеземских съездов с консолидировавшей общественников программой [Рус. ведом., 1902, № 4].

Многие выработанные пироговцами предложения имели общественно-политическое звучание. Так, было подготовлено ходатайство к Министерству просвещения о допущении женщин на медицинские факультеты университетов и других высших учебных заведений [Николай Иванович Пирогов и его наследие, с. 192]. Данный вопрос был поднят земским врачом Д. Н. Жбанковым. Запросы женщин в высшем образовании как в качественном, так и в количественном отношениях не могли быть удовлетворены, по его мнению, существующими курсами и институтами. Жбанков инициировал также обсуждение вопроса отмены телесных наказаний для крестьян по приговорам волостных судов. Ссылаясь на статистику по различным местностям империи, он заявил, что телесное наказание в России в последние годы усиливается [Рус. ведом., 1902, № 6]. Пироговцы подали правительству ходатайство об отмене телесных наказаний, а 24 августа 1904 г. был издан соответствующий указ.

Однако наиболее существенным для Пироговского съезда был признан вопрос о санитарно-гигиеническом направлении деятельности земств. Доклад по этому поводу почетного председателя съезда профессора М. Я. Капустина стал подлинным гимном земскому самоуправлению. Организацию санитарно-гигиенической деятельности в деревнях Капустин признал достижением земских учреждений, как и просветительскую деятельность земских врачей, которая приблизила, по его словам, медицину к населению и повысила уровень его доверия к медицинскому персоналу. Завершился съезд пожеланием к врачам консолидироваться «в одну семью деятелей на общественную пользу... объединенную гуманными стремлениями, любовью 
к своему народу...». Политическое кредо Пироговского съезда 1902 г. было выдержано в реформистском духе: «В массовой жизни, - заметил Капустин, - нужна эволюция, а не катастрофа, не переворот» [Рус. ведом., 1902, № 11].

Высказанное съездом представление о земстве как о лучшем органе для проведения социальных и культурных мероприятий и сопряженная с ним идея о необходимости расширения компетенции земских учреждений в скором времени прозвучат в заключениях местных комитетов Особого совещания о нуждах сельскохозяйственной промышленности 1902 г. Между тем, Пироговский съезд высказал ее раньше: комитеты завершили свою работу в начале 1903 г., а собранные ими материалы стали достоянием общественности в 1904 г. Занимавшееся с января 1902 г. по март 1905 г. созданием объективной картины состояния сельского хозяйства в России совещание вышло за рамки свой задачи и способствовало подъему освободительного движения на новый уровень. Участвовавшие в нем дворянеземлевладельцы, чиновники, земцы и др. констатировали, что Отечество находится в опасности, и его спасение придет из земств, полномочия которых власти следовало расширить вплоть до разрешения созыва общеземских съездов и введения мелкой всесословной земской единицы. Велась речь также о назревшей потребности улучшить положение крестьян, ликвидировать их социальное и правовое неравноправие и пр. [Миронов, с. 17-18]. Идейный настрой участников совещания воздействовал на идеологию съездов в 1903-1904 гг.

\section{Паритет профессиональных и общегражданских требований в резолюциях Учительского съезда конца 1902 - начала 1903 г.}

Спустя немногим менее года после Пироговского съезда Москва встречала делегатов Первого всероссийского съезда представителей обществ вспомоществования лицам учительского звания. Учительский съезд, как и Пироговский, проходил на Святках, с 28 декабря 1902 по 7 января 1903 г.

Его планировалось созвать еще зимой 1901-1902 гг. Инициатива исходила от Московского общества попечения об улучшении быта учащих в городских начальных училищах и его лидера князя Павла Д. Долгорукова. Ему удалось убедить министра народного просвещения П. С. Ванновского в полезности публичного обсуждения вопросов, волнующих учительское сообщество. Идея Долгорукова улучшить учительский быт совместными усилиями правительства и благотворительных обществ показалась Ванновскому благотворной. Она шла в фарватере проводимых им мероприятий по отмене наиболее одиозных мер его предшественника Н. П. Боголепова [Иванов, c. 142-143]. Однако в расчете, что учительские общества взаимопомощи ограничатся обсуждением вопросов материального положения народных учителей, определенных для них Нормальным уставом 1894 г., 
Ванновский просчитался. Разрешение на созыв съезда было дано Министерством просвещения только в ноябре 1901 г., и его решено было отсрочить на год [РГИА. Ф. 1284. Оп. 187. 1904. Д. 370. Л. 4].

Среди устроителей учительского съезда в Москве были такие представители земского либерализма, как ярославский земец князь Д. И. Шаховской, орловский предводитель дворянства М. А. Стахович, председатель Суджанской уездной земской управы Курской губернии князь Петр Д. Долгоруков. Все они принимали участие в работе кружка «Беседа» и в издании журнала «Освобождение», являлись инициаторами «Союза освобождения». В работе съезда участвовали также деятели народного просвещения Н. В. Чехов, В. П. Вахтеров, Э. О. Вахтерова. Председателем был избран Павел Долгоруков. Съезд посетили делегаты от 74 учительских обществ, то есть практически всех обществ империи. Помимо учителей начальной школы, здесь собрались преподаватели средней школы, земские деятели, юристы, врачи, профессора и писатели [Рус. ведом., 1902, № 357].

Школьный вопрос активно обсуждался на собраниях кружка «Беседа» той поры. «Собеседники» признали его одним из ключевых во взаимоотношениях земств и администрации и высказались за расширение в школе общественного присутствия [Соловьев, с. 119]. Эта идея стала основополагающей на учительском съезде. Делегаты сосредоточились на анализе экономической и правовой сторон учительского быта, а также затронули такую насущную нужду учительского сословия, как объединение на почве профессиональных интересов.

Тема объединения народных учителей проходила красной нитью через значительную часть выступлений. Начало было положено князем Петром Долгоруковым, сделавшим доклад о необходимости общения учителей. Количественные параметры объединения назывались разные: по мнению одних докладчиков, учителя могли составить корпорацию в 25 тыс. чел., по словам других, в 80-100 тыс. Наиболее желательной формой объединения учительских организаций был признан Всероссийский учительский союз, связывающий все действующие в империи учительские общества [РГИА. Ф. 1284. Оп. 187. 1904. Д. 370. Л. 14 об. -16 об.]. Проектированный съездом Всероссийский союз учителей и деятелей по народному образованию был создан весной 1905 г. и превратился в одну из влиятельных профессионально-политических организаций.

Выработанный съездом доклад о правовом положении учителей основывался на идее их освобождения от опеки государства, а также участия в выборных органах: земских собраниях, городских думах, сельских и волостных сходах. Это была своего рода «декларация прав народного учителя», в которую вошли право на пенсионное обеспечение в размере учительского жалованья, на предоставление отпуска с сохранением содержания, на возможность увольнения учителя по суду, а не на основании данных о его политической неблагонадежности. Доклад был прочитан на секционном заседании и снят с об- 
суждения под нажимом наблюдателей от правительства инициатором идеи профессионально-технического образования инженером К. К. Мазингом. В ответ на это более ста делегатов покинули заседание, направив письменный протест распорядительному комитету. «Крамольный» доклад не был допущен к прочтению, но обсуждался на закрытом заседании секции и был опубликован [Рус. ведом., 1903, № 6; РГИА. Ф. 1284. Оп. 187. 1904. Д. 370. Л. 17 об. -20].

Заслугой учительского съезда явился новаторский взгляд на учительскую корпорацию как на независимую, свободно взаимодействующую внутри и вовне, объединенную миссией служения народу [РГИА. Ф. 1284. Оп. 187. 1904. Д. 370. Л. 22]. Заявлявшиеся учителями профессиональные требования соседствовали с общегражданскими лозунгами. Предоставление учителям гражданских прав связывалось с либеральным проектом введения мелкой земской единицы и превращения учителя в ее полноправного участника. Высказывалось пожелание об уравнивании крестьян в правах с другими сословиями [Рус. ведом., 1903, № 1, 3, 4, 5]. Эти идеи, как мы видели, были высказаны также участниками Совещания о нуждах сельскохозяйственной промышленности.

Общая тональность заседаний учительского съезда рубежа 1902-1903 гг. была возбужденной. Аудитория реагировала на многие предложения аплодисментами и криками «Браво!». Увещевания председателей секций и съезда о необходимости избегать резкостей в прениях не работали [РГИА. Ф. 1284. Оп. 187. 1904. Д. 370. Л. 13]. Особое неприятие властей вызвало желание учителей объединиться в общеимперском масштабе [Там же. Л. 25 об.]. Министр внутренних дел В. К. Плеве постановил впредь не разрешать съездов учительских обществ, эксплуатировавших тему объединения и поднимавших политические вопросы [Зубков, с. 676].

Учительский съезд рубежа 1902-1903 гг. явился переходным этапом от профессионального к гражданскому. Он способствовал как сплочению и самоорганизации учителей, так и вовлечению их в освободительное движение.

\section{Съезд как акция протеста}

На рубеже 1903-1904 гг. в России заседали III съезд деятелей по техническому и профессиональному образованию и IX Пироговский съезд врачей. Несмотря на узкоспециальные задачи того и другого, они, по выражению современника, символизировали «чрезвычайно высокий подъем общественной температуры»[Итоги III съезда, с. 310].

III съезд деятелей по техническому и профессиональному образованию проходил в Петербурге с 26 декабря 1903 г. по 4 января 1904 г. Он был созван Русским техническим обществом, чтобы способствовать развитию техники и профессиональной деятельности. Однако его делегаты расширили повестку, задавшись целью рассмотреть во- 
просы профессионального образования в контексте общих условий развития образования в империи.

На съезд прибыло свыше 3 тыс. делегатов - преподавателей учебных заведений, преимущественно технических и коммерческих, народных учителей, писателей, деятелей городских и земских учреждений [Рус. ведом., 1904, № 11; Два съезда, с. 22]. В качестве почетных гостей на церемонии открытия присутствовали крупные чиновники: министр земледелия и государственных имуществ А. С. Ермолов, товарищ министра просвещения С. М. Лукьянов, попечитель Московского учебного округа П. А. Некрасов [Дневник III-го съезда русских деятелей по техническому и профессиональному образованию, с. 2], что символизировало заинтересованность государства в трудах съезда.

Заседания технического съезда были объявлены публичными, а его резолюции отразили требования, высказываемые в подцензурном журнале «Освобождение», и немного позднее наиболее рельефно - на ноябрьском общеземском съезде 1904 г. [Либеральное движение, с. 92-93]. В постановлениях 10-й секции, посвященной образованию рабочих, шла речь о всеобщем начальном образовании, свободе слова, печати, собраний и союзов, восьмичасовом рабочем дне и обязательном государственном страховании рабочих на случай увечья, болезни, старости и инвалидности. В 1-й секции, обсуждавшей высшее образование, прошли резолюции об уничтожении черты еврейской оседлости, вероисповедных и национальных ограничений. В ходе неформальных встреч требование свободы личности, являвшееся сердцевиной конституционной программы, трансформировалось в призыв к свержению самодержавно-бюрократического строя. Подобное обращение, адресованное к интеллигенции и народу, прозвучало на товарищеском обеде 400 техников [Итоги III съезда, с. 310].

Делегаты съезда пришли к заключению, что введение всеобщего начального обучения и иные меры, призванные повысить образовательный уровень населения, должны быть делом общественных учреждений. Был провозглашен блок требований по расширению полномочий земских органов: передаче им министерских и церковноприходских школ, предоставлению новых сфер обложения, введению мелкой земской единицы и расширению представительства населения [Рус. ведом., 1904, № 11].

5 января 1904 г. постановлением петербургского градоначальника В. Э. Фриша заседания технического съезда были закрыты. Согласно формулировке полицейского отчета, поводом послужило то, что прения вышли из-под контроля, сводясь «преимущественно к резкой критике распоряжений Министерства народного просвещения и высказыванию пожеланий о предоставлении свобод», между тем как «собранные по специальным вопросам съезды должны разрабатывать исключительно свой материал и не касаться вопросов, разрешение которых им не предоставлено» [РГИА. Ф. 1284. Оп. 187. 1904. Д. 370 . Л. 57 об. -58$].$ 
Председатели и секретари секций были вызваны на допрос в Петербургское охранное отделение. Ряд делегатов был арестован, а трудившийся в 10-й секции по подготовке рабочих к техническому и профессиональному образованию Г. А. Фальборк был сослан на пять лет в Якутскую область за организацию антиправительственной работы. В ответ на полицейские репрессии группа делегатов съезда собралась на частное совещание и высказалась «против существующего режима, который возвел в принцип систематическое уничтожение общественной самодеятельности и общественного мнения в России». В общественном мнении технический съезд был признан «подлинным I съездом русских конституционалистов» [Итоги III съезда, с. 310-311] и отождествлялся с парламентом, принявшим конституционные решения [ГАРФ. Ф. 102.00. 1904. Д. 200. Л. 30].

IX съезд русских врачей в память Н. И. Пирогова открылся в заключительный день работы технического съезда. Он проходил с 4 по 11 января 1904 г. Вопреки пропускному режиму, его заседания посещала значительная часть аудитории распущенного технического съезда, принеся с собой высокий градус критических настроений [Там же. Л. 25-25 об., 28]. Как и его собрат, Пироговский съезд отказался от формата ходатайств во властные инстанции и перешел к «принципиальным постановлениям» [Скибневский, с. 3; Рус. ведом., 1904, № 12].

IX Пироговский съезд врачей был самым многочисленным из всех ранее организованных врачебных съездов. Число его участников превысило 2130 чел. [Рус. ведом., 1904, № 12], число посетителей на церемонии открытия достигло 6 тыс. [Брэдли, с. 410]. 85 \% собравшихся представляли 34 земские губернии, 39,4 \% делегатов - Петербург, и 60,6 \% - провинцию, немногим более половины «нестоличных» участников приехали из университетских городов: Москвы, Киева, Харькова, Одессы и Казани. Помимо представителей Центральной России и Поволжья, в работе съезда участвовали врачи остзейских и привислинских губерний, Кавказа и Войска Донского, Сибири и Средней Азии. По гендерному составу 86 \% делегатов были мужчинами. По профессиональной принадлежности преобладали земские и вольнопрактикующие врачи [Скибневский, с. 2]. Преобладание земских врачей - наиболее организованных и идейных представителей врачебной профессии - усилило оппозиционный настрой участников.

Визитной карточкой врачебного съезда была плохая организация. Заседания целого ряда секций и подсекций происходили одновременно, что не позволяло всем заинтересованным их посещать, постоянно менялось их расписание. Так, имевшая наибольший общественный резонанс секция общественной медицины и гигиены была разделена на 11 подсекций (земской медицины, городской медицины, фабричной и горнозаводской медицины и др.), собиравшихся в одно и то же время. Разобщение делегатов было спланированной акцией со стороны председателя организационного комитета съезда товарища министра народного просвещения С. М. Лукьянова и избранного председателя профессора 
хирургии Казанского университета В. И. Разумовского, опасавшихся, что деятельность съезда выйдет за границы заявленных вопросов [Скибневский, с. 11; С IX Пироговского съезда, с. 333].

Однако, несмотря на желание организаторов сконцентрироваться на профессиональной повестке, врачебный съезд пошел по пути, проторенному техническим. Пироговцы видели способ решения той или иной медицинской проблемы в проведении политических реформ. Они постановили, что борьба с алкоголизмом, туберкулезом и детской смертностью, представляющими собой социальное бедствие огромной важности, возможна только на почве широких социальных реформ и при полном обеспечении свободы мнений, слова, печати и собраний. Гражданские свободы признавались врачами неотъемлемым условием для распространения сведений об истинных причинах народных бедствий. Объявив основанием народного просвещения и здравоохранения развитие в народе медико-гигиенических знаний, делегаты связали их с отменой ограничений печатного и устного слова, а также с ликвидацией вмешательства администрации в жизнь обществ и союзов. Признав организацию акушерской и гинекологической помощи населению в земских губерниях более успешной, нежели в неземских, делегаты высказались за распространение земств на всю империю и расширение представительства в них населения [Николай Иванович Пирогов и его наследие, с. 193-194; Скибневский, с. 3].

Камертоном многих речей и постановлений делегатов врачебного съезда было недоверие к власти. Так, врачи-общественники Д. Н. Жбанков, Н. И. Долгополов и А. И. Шингарев выступили против принудительного помещения в больницы алкоголиков из опасения, что туда станут направлять неугодных. Болезненность российского населения врачи объясняли его безысходной нуждой, производной от «ненормального экономического и политического строя» [ГАРФ. Ф. 102.00. 1904. Д. 200. Л. 23, 25 об. -26].

В соединенном заседании секций общественной медицины, гигиены и детских болезней 9 января 1904 г., где председательствовал курский земский деятель и член «Союза освобождения» В. И. Долженков, осуждались факты гонений на врачей из-за их вероисповедания [Рус. ведом., 1904, № 12] и было предложено положить конец дискриминации евреев, а также представителей иных притесняемых народов. Ответственность за организацию еврейских погромов пироговцы возлагали на правительство [ГАРФ. Ф. 102.00. 1904. Д. 200. Л. 25 об.].

Делегаты секции фабричной и горнозаводской медицины приняли постановления, определившие на ближайшую перспективу повестку дня профессионального рабочего движения. Предлагалось отменить телесные наказания, применяемые фабричной администрацией. Формой обеспечения в случае болезни, старости и инвалидности было признано обязательное государственное страхование рабочих. Оно понималось как результат коллективных усилий общественных учреждений, рабочих, предпринимателей и врачей. Перемены к луч- 
шему в обеспечении рабочих медицинской помощью связывались с передачей фабричной и горнозаводской медицины органам самоуправления [C IX Пироговского съезда, с. 332; Рус. ведом., 1904, № 8; ГАРФ. Ф. 102.00. 1904. Д. 200. Л. 26 об.].

Общая тональность речей показалась правительству настолько оппозиционной, что было решено запретить медикам публичное прочтение итоговых резолюций. Церемония закрытия съезда ограничилась выступлением председателя Разумовского, признавшего съезд удавшимся, после чего официальные лица покинули зал заседаний [Рус. ведом., 1904, № 12, № 13; С IX Пироговского съезда, с. 333]. Однако выступления делегатов и прочтение резолюций съезда с требованиями свобод и призывом к борьбе с правительством продолжались. Игра военного оркестра их заглушала. Съезд завершился пением революционных песен «Отречемся от старого мира!» и «Марсельеза». Среди публики распространялись номера журнала «Освобождение», а наиболее активные делегаты были арестованы [ГАРФ. Ф. 102.00. 1904. Д. 200. Л. 27-28].

«Освобождение» определило главный политический итог IX съезда врачей лаконичной фразой: «люди перестали бояться говорить», усмотрев в этом «большое приобретение последнего времени» [C IX Пироговского съезда, с. 333]. Завсегдатай врачебных съездов Жбанков признал форум 1904 г. «одним из главных инициаторов освободительного движения» в России [Жбанков, с. 22].

Проявившееся на IX Пироговском съезде оппозиционное настроение усилилось на мартовском чрезвычайном Пироговском съезде по борьбе с холерой 1905 г. Его резолюции осуждали правительство за политику «безграничного административного произвола, бесконтрольного хозяйничанья в финансах, завоевательных авантюр», а врачи призывались к «энергичной борьбе рука об руку с трудящимися массами против бюрократического строя для полного его устранения». Венцом конституционных требований явился лозунг созыва Учредительного собрания [Право, 1905, № 14, стб. 1103-1104]. Московский вице-губернатор В. Ф. Джунковский признал главным итогом съезда почти поголовное вовлечение земского медицинского персонала в движение за установление конституционного образа правления [ГАРФ. Ф.102.00. 1904. Д. 200. Л. 62-63].

Январские съезды 1904 г. явились важной вехой в развитии оппозиционных настроений участвовавших в них профессиональных специалистов. Обретение съездовским движением политико-гражданского характера было признаком серьезной обеспокоенности русского интеллигентного общества проблемами развития страны, а также убежденности в неспособности правительства к их решению. Сходные идеи высказывались на особых совещаниях о нуждах сельскохозяйственной промышленности 1902-1905 гг, а также на ноябрьском земском съезде 1904 г. Профессиональные съезды начала 1904 г. стали преамбулой к общеземским съездам, устраивавшимся с ноября 1904 г. по ноябрь 
1905 г. и составившим законченный цикл публичных собраний, родственных по идеологии и составу участников. С. А. Муромцев признал их переходной стадией от общественной деятельности в доконституционных рамках к парламентской работе [Кокошкин, с. 209].

История общественных съездов 1902-1904 гг. служит пособием для изучения основных стадий, пройденных общественным движением в канун Первой русской революции. Съезды стали красноречивой демонстрацией того, как требования представителей мирных профессий трансформировались в идеологию конституционных реформ и в манифестации недоверия самодержавию.

Конституционные требования в съездовском движении явились следствием долго сдерживавшейся неудовлетворенной потребности образованных людей к участию в политической жизни страны. Углубившись в критический анализ российской действительности, профессиональные специалисты пришли к выводу о невозможности прогресса науки и техники, медицины и образования в условиях архаичного государственного строя и поставили задачу его реформирования. Они стали местом диалога профессиональных специалистов с земскими деятелями, способствовали осознанию ими общности интересов. Их делегаты связывали улучшения в своих областях с расширением участия общественности в государственном управлении и развитием местного самоуправления, дарованием подданным гражданских и политических прав. Идеи и принципы, получившие развитие на форумах начала века, сыграли определяющую роль в формировании профессиональных нужд и самосознания.

Наряду с иными высказывавшими конституционные идеи институциями, профессиональные съезды начала прошлого века явились важным событием в идейной подготовке Первой русской революции. Делая политические заявления и вырабатывая резолюции конституционного содержания, делегаты съездов способствовали мобилизации общественного мнения, а также развитию организованной общественной деятельности в публичной сфере в условиях отсутствия законодательно закрепленных политических свобод и представительных учреждений.

\section{Список литературы}

Брэдли Дж. Общественные организации в царской России. М. : Новый хронограф, 2012. $447 \mathrm{c}$.

ГАРФ. Ф. 102.00. 1904. Д. 200.

Два съезда // Мир Божий : ежемес. лит. и науч.-поп. журн. для самообразования. 1904. № 2. C. 22-24.

Дневник III-го съезда русских деятелей по техническому и профессиональному образованию в С.-Петербурге (26 декабря 1903 - 6 января 1904 года), издаваемый распорядительной комиссией съезда / под ред. К. И. Диксона. № 1-11. Пг. : [Б. и.], [1903-1904]. 
Жбанков Д. Н. Статистические данные о врачебных съездах // Журн. Общества русских врачей в память Н. И. Пирогова. 1905. № 1. С. 3-24.

Зубков И. В. Педагогические организации // Самоорганизация российской общественности в последней трети XVIII - начале XX в. / отв. ред. А. С. Туманова. М. : РОССПЭН, 2011. С. 647-690.

Иванов А. Е. Высшая школа Российской империи XVIII - начала XX века : избр. ст. М. : Принципиум, 2019. 702 с.

Исторический урок // Освобождение. 1904. № 57.2 (15) окт. С. 116-117.

Итоги III съезда деятелей по техническому образованию // Освобождение. 1904. № 17 (41). 5 (18) февр. С. 310-311.

Канищев В. Ю. Роль журнала «Освобождение» в формировании конституционнодемократической партии : дис. ... канд. ист. наук. М. : [Б. и.], 2006. 301 с.

Кокошкин Ф. Ф. С. А. Муромцев и земские съезды // Сергей Андреевич Муромцев : сб. ст. М. : Изд. М. и С. Сабашниковых, 1911. С. 205-250.

Либеральное движение в России. 1902-1905 гг. / сост. Д. Б. Павлов. М. : РОССПЭН, 2001. 646 с.

Медушевский $A$. Н. Демократия и авторитаризм: российский конституционализм в сравнительной перспективе. М. : РОССПЭН, 1998. 650 с.

Миронов Б. Н. Политика versus истина : Особое совещание о нуждах сельскохозяйственной промышленности 1902-1905 гг. // Вестн. С.-Петерб. ун-та. Сер. 2. 2008. Вып. 1. С. 8-30.

Николай Иванович Пирогов и его наследие : Пироговские съезды. 1810-1910/ под ред. М. М. Гран, 3. Г. Френкеля и А. И. Шингарева. СПб. : Т-во Р. Голике и А. Вильборг, 1911. [7], 257, XXXV с.

Право. 1905. № 14.

РГИА. Ф. 1284. Оп. 187. 1904. Д. 370.

Рус. ведом. 1902. № 4, 6, 7, 11, 357; 1903. № 1, 3, 4, 5, 6; 1904. 6, 7, 8, 11, 12, 13 .

С IX Пироговского съезда // Освобождение. 1904. № 19 (48). 7 (20) марта. С. 332-333.

Скибневский А. И. Девятый съезд русских врачей в память Н. И. Пирогова : Краткий общий обзор деятельности съезда. [М. : Б. и., 1904]. 12 с.

Соловьев K. А. Кружок «Беседа». В поисках новой политической реальности : 1899-1905. М. : РОССПЭН, 2009. 288 с.

Степанский А. Д. Либеральная интеллигенция в общественном движении России на рубеже XIX-XX вв. // Ист. зап. Т. 109. М. : Наука, 1983. С. 64-94.

Шацилло К. Ф. Русский либерализм накануне революции 1905-1907 гг. : Организация, программы, тактика. М. : Наука, 1985. 347 с.

Шелохаев В. В. Либерализм в России в начале ХХ века. М. : РОССПЭН, 2019. 504 с.

Russia's Missing Middle Class. The Professions in Russian History / ed. by H. D. Balzer. Armonk, N. Y. : M. E. Sharpe, 1996. 330 p.

\section{References}

Balzer, H. D. (Ed.). (1996). Russia's Missing Middle Class. The Professions in Russian History. Armonk, N. Y., M. E. Sharpe. 330 p.

Bradley, J. (2012). Obshchestvennye organizatsii v tsarskoi Rossii [Voluntary Associations in Tsarist Russia]. Moscow, Novyi khronograf. 447 p.

Dikson, K. I. (Ed.). (1903-1904). Dnevnik III-go s"ezda russkikh deyatelei po tekhnicheskomu i professional'nomu obrazovaniyu v S.-Peterburge (26 dekabrya 1903 6 yanvarya 1904 goda), izdavaemyi rasporyaditel'noi komissiei s"ezda [Record of the $3^{\text {rd }}$ Congress of Russian Technical and Professional Education Leaders in St Petersburg (26 December 1903 - 6 January 1904), Published by the Administrative Commission of the Congress]. No. 1-11. St Petersburg, S. n.

Dva s"ezda [Two Congresses]. (1904). In Mir Bozhii. Ezhemesyachnyi literaturnyi i nauchno-populyarnyi zhurnal dlya samoobrazovaniya. No. 2, pp. 22-24.

GARF [State Archive of the Russian Federation]. Stock 102.00. 1904 Year. Dos. 200. 
Gran, M. M., Frenkel', Z. G., Shingarev, A. I. (Eds.). (1911). Nikolai Ivanovich Pirogov i ego nasledie. Pirogovskie s"ezdy [Nikolai Ivanovich Pirogov and His Legacy. Pirogov Congresses]. St Petersburg, Tovarishchestvo R. Golike i A. Vil'borg. [7], 257, XXXV p.

Istoricheskii urok [Historical Lesson]. (1904). In Osvobozhdenie. No. 57. October 2 (15), pp. 116-117.

Itogi III s"ezda deyatelei po tekhnicheskomu obrazovaniyu [Results of the $3^{\text {rd }}$ Congress of Technical Education Leaders]. (1904). In Osvobozhdenie. No. 17 (41). February 5 (18), pp. 310-311.

Ivanov, A. E. (2019). Vysshaya shkola Rossiiskoi imperii XVIII - nachala XX veka. Izbrannye stat' $i$ [Higher Schools of the Russian Empire of the $18^{\text {th }}-$ Early $20^{\text {th }}$ Century. Selected Articles]. Moscow, Printsipium. 702 p.

Kanishchev, V.Yu. (2006). Rol'zhurnala "Osvobozhdenie" $v$ formirovanii ko-stitutsionnodemokraticheskoi partii [The Role of the Osvobozhdenie Magazine in the Formation of the Constitutional Democratic Party]. Dis. ... kand. ist. nauk. Moscow, S. n. 301 p.

Kokoshkin, F. F. (1911). S. A. Muromtsev i zemskie s"ezdy [S. A. Muromtsev and Zemstvo Congresses]. In Sergei Andreevich Muromtsev. Sbornik statei. Moscow, Izdatel'stvo M. i S. Sabashnikovykh, pp. 205-250.

Medushevskii, A. N. (1998). Demokratiya i avtoritarizm: rossiiskii konstitutsionalizm v sravnitel'noi perspektive [Democracy and Authoritarianism: Russian Constitutionalism in Comparative Perspective]. Moscow, ROSSPEN. 650 p.

Mironov, B. N. (2008). Politika versus istina. Osoboe soveshchanie o nuzhdakh sel'skokhozyaistvennoi promyshlennosti 1902-1905 gg. [Politics versus Truth: A Special Meeting on the Needs of the Agricultural Industry 1902-1905]. In Vestnik SanktPeterburgskogo universiteta. Seriya 2. Iss. 1, pp. 8-30.

Pavlov, D. B. (Ed.). (2001). Liberal'noe dvizhenie v Rossii. 1902-1905 gg. [The Liberal Movement in Russia. 1902-1905]. Moscow, ROSSPEN. 646 p.

Pravo [Pravo]. (1905). No. 14.

RGIA [Russian State Historical Archive]. Stock 1284. List 187. 1904 Year. Dos. 370.

Russkie vedomosti [Russkie vedomosti]. (1902). No. 4, 6, 7, 11, 357; (1903). No. 1, 3, 4, 5, 6; (1904). No. 6, 7, 8, 11, 12, 13.

S IX Pirogovskogo s"ezda [From the $9^{\text {th }}$ Pirogov Congress]. (1904). In Osvobozhdenie. No. 19 (48). March 7 (20), pp. 332-333.

Shatsillo, K. F. (1985). Russkii liberalizm nakanune revolyutsii 1905-1907 gg. Organizatsiya, programmy, taktika [Russian Liberalism on the Eve of the Revolution of 1905-1907. Organisation, Programs, Tactics]. Moscow, Nauka. 347 p.

Shelokhaev, V. V. (2018). Liberalizm v Rossii v nachale XX veka [Liberalism in Russia at the Beginning of the $20^{\text {th }}$ Century]. Moscow, ROSSPEN. $504 \mathrm{p}$.

Skibnevskii, A. I. (1904). Devyatyi s"ezd russkikh vrachei v pamyat' N. I. Pirogova. Kratkii obshchii obzor deyatel'nosti s"ezda $\left[9^{\text {th }}\right.$ Congress of Russian Doctors in Memory of N. I. Pirogov. A Brief Overview of the Congress Activities]. Moscow, S. n. 12 p.

Solov'ev, K. A. (2009). Kruzhok "Beseda". V poiskakh novoi politicheskoi real'nosti. 1899-1905 [The "Beseda" Circle. In Search for a New Political Reality. 1899-1905]. Moscow, ROSSPEN. 288 p.

Stepanskii, A. D. (1983). Liberal'naya intelligentsiya v obshchestvennom dvizhenii Rossii na rubezhe XIX-XX vv. [The Liberal Intelligentsia in the Social Movement of Russia at the Turn of the $20^{\text {th }}$ Century]. In Istoricheskie zapiski. Vol. 109. Moscow, Nauka, pp. 64-94.

Zhbankov, D. N. (1905). Statisticheskie dannye o vrachebnykh s"ezdakh [Statistical Data on Medical Congresses]. In Zhurnal Obshchestva russkikh vrachei v pamyat' N. I. Pirogova. No. 1, pp. 3-24.

Zubkov, I. V. (2011). Pedagogicheskie organizatsii [Educational Institutions]. In Tumanova, A. S. (Ed.). Samoorganizatsiya rossiiskoi obshchestvennosti v poslednei treti XVIII - nachale XXv. Moscow, ROSSPEN, pp. 647-690. 